\title{
PENGGUNAAN PLATFORM GOOGLE CLASSROOM DAN WHATSAPP SEBAGAI MEDIA PEMBELAJARAN DARING PADA MASA PANDEMIC COVID 19
}

\author{
Fahad Achmad Sadat \\ STIT Buntet Pesantren Cirebon \\ fahadmalq@gmail.com
}

\begin{abstract}
This study was intended to explore the use of the Google Classroom Platform and WhatsApp as Online Learning Media in the Madrasah Aliyah Nahdlatul Ulama during the COVID 19 pandemic with the spirit of Merdeka Belajar. This research approach, that is, is descriptive qualitative. Data collection techniques using interview and observation techniques. Data analysis techniques using interactive data analysis techniques. Based on research on the use of Google classroom and WhatsApp as online learning media for students of Madrasah Aliyah Nahdatul Ulama (MANU) Putra Buntet Cirebon Islamic Boarding School during the pandemic COVID 19 with the spirit of Freedom Learning runs smoothly supported by institutions that facilitate the online learning process and parents of students who support children so that online learning run well.
\end{abstract}

Keywords: Online Learning, Google Classroom, Whatsapp, Covid-19

\begin{abstract}
Abstrak
Penelitian ini bertujuan untuk mengeksplorasi Penggunaan Platform Google Classroom dan WhatsApp sebagai Media Pembelajaran Daring di Madrasah Aliyah Nahdlatul Ulama pada masa pandemic COVID 19 dengan semangat Merdeka Belajar. Pendekatan penelitian ini, yaitu, deskriptif kualitatif. Teknik pengumpulan data menggunakan teknik wawancara dan observasi. Teknik analisis data menggunakan teknik analisis data interaktif. Berdasarkan penelitian penggunaan Google classroom dan WhatsApp sebagai media pembelajaran daring bagi siswa Madrasah Aliyah Nahdatul Ulama (MANU) Putra Buntet Pesantren Cirebon di masa pandemic COVID 19 dengan semangat Merdeka Belajar berjalan lancar didukung oleh lembaga yang menfasilitasi proses pembelajaran daring dan orang tua siswa yang mensuport anakanaknya sehingga pembelajaran daring berjalan dengan baik.
\end{abstract}

Keywords: Pembelajaran Daring, Google Classroom, Whatsapp, Covid-19

\section{Pendahuluan}

Tam dan El Azar (2020) menyatakan pandemi virus corona menyebabkan tiga perubahan mendasar di dalam pendidikan global. Pertama, mengubah cara jutaan orang dididik. Kedua, solusi baru untuk pendidikan yang dapat membawa inovasi yang sangat dibutuhkan. Ketiga, adanya
kesenjangan digital menyebabkan pergeseran baru dalam pendekatan pendidikan dan dapat memperluas kesenjangan.

Luthra \& Mackenzi (2020) menyebut ada empat cara COVID-19 mengubah cara kita mendidik generasi masa depan. Pertama, bahwa proses pendidikan di 
seluruh dunia semakin saling terhubung. Kedua, pendefinisian ulang peran pendidik. Ketiga, mengajarkan pentingnya keterampilan hidup di masa yang akan datang. Dan, keempat, membuka lebih luas peran teknologi dalam menunjang pendidikan.

UNICEF, WHO dan IFRC (2020) dalam COVID-19 Prevention and Control in School menyebut bahwa ketika situasi persebaran virus semakin cepat maka sekolah harus ditutup dan proses pendidikan harus tetap berjalan melalui kegiatan pembelajaran online dengan menggunakan berbagai media. Data UNESCO (2020) menyebut 1,5 miliar siswa dan 63 juta guru di tingkatan sekolah dasar hingga menengah di 191 negara yang terdampak pandemi Covid-19, sesuatu yang tidak pernah terjadi sebelumnya. Dunia pendidikan kemudian, 'terpaksa' putar haluan untuk mengubah cara belajar berbasis perjumpaan tatap muka menjadi pembelajaran daring. Transformasi digital secara terpaksa ini adalah cara yang paling aman untuk memutus penyebaran wabah akibat virus corona. Sebab, hak para siswa untuk mendapatkan pendidikan tetap menjadi prioritas tanpa mengabaikan kesehatan dan keselamatan jiwa.

Di Indonesia pembelajaran daring/jarak jauh diatur melalui Surat Edaran Kemdikbud No 4 Tahun 2020 mengenai Pelaksanaan Pendidikan Dalam Masa Darurat Coronavirus Disease (Covid-19). Ada tiga poin kebijakan terkait pembelajaran daring, pertama, pembelajaran daring/jarak jauh untuk memberi pengalaman belajar yang bermakna, tanpa terbebani tuntutan menuntaskan seluruh capaian kurikulum untuk kenaikan kelas maupun kelulusan.
Kedua, dapat difokuskan pada pendidikan kecakapan hidup, antara lain mengenai pandemi Covid-19. Ketiga, aktivitas dan tugas pembelajaran dapat bervariasi antar siswa, sesuai minat dan kondisi masingmasing, termasuk mempertimbangkan kesenjangan akses/fasilitas belajar di rumah. Ketiga hal tersebut merupakan strategi Merdeka Belajar dalam hal membangun platform pendidikan nasional berbasis teknologi: yang berpusat pada siswa, interdisipliner, relevan, berbasis proyek dan kolaboratif.

Terkait pembelajaran daring, sarana pendukung pembelajaran daring/jarak jauh banyak sekali platform-platform bermunculan guna membantu dan menunjang proses pembelajaran daring/PJJ agar dapat terlaksana dengan baik. Salah satunya adalah Google Classroom yang dapat menyediakan kelas online, sehingga memudahkan bagi siswa untuk mengakses konten pembelajaran dimana saja (Hakim, 2016). Selain itu, penggunakan Google Classroom dapat menghemat penggunaan kertas dan juga membuat pembelajaran lebih interaktif sehingga minat siswa untuk belajar tetap tinggi.

Google Classroom merupakan sebuah aplikasi yang memungkinkan terciptanya ruang kelas di dunia maya. Selain itu, google classroom bisa menjadi sarana distribusi tugas, submit tugas bahkan menilai tugas-tugas yang dikumpulkan. Google Classroom dapat mempermudah guru dan siswa dalam melakukan proses pembelajaran. Salah satu keunggulan dari Google Classroom adalah siswa dapat melakukan diskusi secara online baik dengan guru atau siswa lainnya dengan menggunakan aplikasi tersebut. 
Selain platform kelas online keberadaan social media juga membantu pada pelaksanaan pembelajarang daring. Siswa pada saat ini sudah banyak yang mempunyai social media berupa WhatsApp, Instagram, Facebook, Youtube dan sebagainya. Penggunaan media sosial dari siswa tersebut hanya sebatas untuk berkomunikasi dengan teman-teman yang lain saja. Salah satu media sosial yang sering digunakan yaitu, WhatsApp. Mengenai mengapa siswa/remaja lebih banyak menghabiskan waktunya hanya untuk bermedia sosial, seperti pendapat yang dikemukakan oleh Hoechsmann dan Poyntz (2012), dengan semua pilihan media yang tersedia saat ini, tidak mengejutkan apabila remaja atau siswa saat ini menjadi seorang yang bisa menguasai banyak media karena lebih bisa menghabiskan waktu dengan media sosial, dibandingkan dengan remaja atau siswa yang lalu.

WhatsApp memiliki berbagai fungsi, di antaranya adalah bisa mengirim pesan, chat grup, berbagi foto, video, dan dokumen. Namun, penggunaan media sosial tersebut tidak terlalu dimanfaatkan sebagai media literasi oleh siswa. Siswa hanya meluangkan waktu dengan Whatsapp sebagai media sosial sebatas berkirim pesan, foto maupun dokumen yang tidak memuat literasi sama sekali. Akibatnya, siswa cenderung apatis terhadap keberadaan WhatsApp sebagai media sosial yang bisa digunakan untuk media literasi.

Kata media berasal dari bahasa Latin, yaitu medius yang artinya tengah, perantara atau pengantar. Media adalah sebuah alat yang dapat digunakan untuk menyalurkan pesan dari pengirim ke penerima sehingga dapat merangsang fikiran, perasaan, perhatian, dan minat serta perhatian peserta didik sedemikian hingga terjadilah proses pembelajaran (Sardiman, 2010). Hal tersebut dapat dipahami bahwa, media adalah sebuah alat bantu yang dijadikan sebagai penyalur pesan untuk mencapai sebuah tujuan pembelajaran (Komsiah, 2012).

Pembelajaran daring di masa pandemic COVID 19 sesuai dengan panduan pembelajaran jarak jauh/ daring bagi guru dengan cara $5 \mathrm{M}$ dalam semangat Merdeka Belajar yaitu: 1) Memanusiakan hubungan yaitu praktik pembelajaran yang dilandasi orientasi pada anak berdasarkan relasi positif yang saling memahami antara guru, siswa dan orang tua, 2) Memahami konsep yaitu praktik pembelajaran yang memandu siswa bukan sekedar menguasai pemahaman mendalam terhadap konsep yang dapat diterapkan di beragam konteks, 3) Membangun keberlanjutan yaitu praktik pembelajaran yang memandu siswa-siswa mengalami rute pengalaman belajar yang terarah dan berkelanjutan melalui umpan balik dan berbagai praktik, 4) Memilih tantangan yaitu praktik pembelajaran yang memandu siswa menguasai keahlian melalui proses yang berjenjang dengan pilihan tantangan yang bermakna, 5). Memberdayakan konteks yaitu praktik pembelajaran yang memandu siswa melibatkan sumber daya dan kesempatan di komunitas sebagai sumber belajar sekaligus kesempatan berkontribusi terhadap perubahan.

Madrasah Aliyah Nahdatul Ulama (MANU) Putra Buntet Pesantren Cirebon, sebagai lembaga pendidikan yang ikut melaksanakan pembelajaran daring juga menggunakan platform Google Classroom dan WhatsApp sebagai media pembelajaran dengan fasilitas memadai, berupa fasilitas 
hotspot dan juga setiap siswa memiliki smartphone untuk bisa mengakses internet.

Maka dari itu perlu diketahui Bagaimana penggunaan Google classroom dan WhatsApp sebagai media pembelajaran daring bagi siswa Madrasah Aliyah Nahdatul Ulama (MANU) Putra Buntet Pesantren Cirebon di masa pandemic COVID 19 dengan semangat Merdeka Belajar?

\section{Metode}

Pendekatan penelitian ini, yaitu, deskriptif kualitatif. Metode penelitian pada penelitian ini adalah simak, catat, dan kajian pustaka. Teknik pengumpulan data menggunakan teknik wawancara dan observasi. Teknik analisis data menggunakan teknik analisis data interaktif.

\section{Hasil dan Pembahasan}

Pelaksanaan kegiatan pembelajaran daring yang dilaksanakan pada siswa Madrasah Aliyah Nahdatul Ulama (MANU) Putra Buntet Pesantren Cirebon adalah sebagai berikut: Persiapan pembelajaran yang dilakukan dengan menggunakan Google Classroom sebagai media pembelajaran. Guru-guru mengunggah untuk memberikan materi, tugas atau penilaian yang dapat dilakukan dengan materi yang sudah diunggah. Dengan menggunakan Google Classroom memberikan kemudahan kepada guru-guru karena bisa memberikan materi baik itu berupa buku, video, atau PPT agar bisa diunduh dan dibaca oleh siswa, dengan tidak lupa memberikan tugas penilaian bagi siswa. Setelah itu memberikan kode kelas online melaui grup WhatsApp.
Berdasarkan hasil penelitian dapat dirangkum bahwa penggunaan media pembelajaran menggunakan google classroom memberikan kemudahan kepada pengguna untuk mendapatkan banyak materi dari internet. Pembelajaran berbasis virtual membuat kegiatan berlangsung secara interaktif antara pendidik dan peserta didik. Penggunaan google clasroom tidak perlu melakukan proses instalasi yang rumit. Setelah seorang administrator melakukan setup account Google, guru dan siswa bisa menggunakan google classroom dengan akun email Google masing-masing. Kelas virtual dapat dibuat dengan google classroom. Tahapan yang dilakukan adalah masuk ke setup account Google terlebih dahulu, kemudian klik Google apps $\rightarrow$ Classroom.

Setelah meng Klik "Buat kelas" maka akan muncul kotak dialog sebelum menggunakan kelas. Pada kotak dialog terdapat kotak kecilyang harus dicentang, kemudian klik lanjutkan. Setelah dibuat maka akan muncul halaman baru yang berisi fitur google classroom. Keterangan pada kolom adalah sebagai berikut:

1. Forum Fitur ini merupakan tempat interaksi antara pendidik dan peserta didik. Ketika pendidik membagikan bahan ajar, tugas, maupun pertanyaan maka akan muncul pemberitahuan di forum tersebut;

2. Tugas Kelas Fitur ini merupakan tempat bagi pendidik untuk membuat tugas.

3. Anggota Pada fitur ini, pemilik akun dapat melihat jumlah anggota termasuk pendidik dan peserta didik, dan pendidik juga dapat menambahkan anggota peserta 
didik dengan memasukkan username e-mail peserta didik.

4. Google Kalender Pendidik dapat membuat schedule time pada fitur ini.

5. Folder Drive Kelas File-file yang sudah diupload akan tersimpan dalam google drive.

6. Tugas Fitur ini untuk membagikan tugas, baik berupa Microsoft Word, Power Point, atau media lainnya.

7. Tugas Kuis Pendidik dapat membuat kuis dengan bantuan google form, baik berupa pilihan ganda maupun uraian. Selain itu, fitur ini juga disertai dengan informasi batas waktu; sehingga ketika peserta didik sudah mengerjakan tugas, maka sistem akan mencatat waktu pengumpulan tugas oleh peserta didik dan pendidik bisa melihat status pengumpulan tugas peserta didik, terlambat atau tepat waktu. Selanjutnya, pendidik bisa memberikan penilaian terhadap tugas yang dikerjakan oleh peserta didik.

8. Pertanyaan Pendidik dapat membuat pertanyaan secara online dan masing-masing peserta didik dapat memberikan jawaban terhadap pertanyaan tersebut.

9. Bahan Ajar Pada fitur ini, pendidik dapat membagikan bahan ajar baik berupa Microsoft word, Power Point, video, maupun media lainnya.

Dalam pelaksanaan pembelajaran, selain dalam Google Classroom juga, berbagi materi pelajaran (menggunakan fitur Forward) dalam WhatsApp Group yang bisa menyimpan dokumen dalam bentuk pdf, microsoft word, excel, dan powerpoint. Maka dari itu, apabila menggunakan WhatsApp berbagi dokumen dengan dengan format/ bentuk di atas jauh lebih mudah. Selain bisa digunakan menyimpan dokumen dengan bentuk atau format di atas, WhatsApp juga bisa meneruskan pesan, sehingga memudahkan apabila siswa ingin berbagi dengan teman yang lain.

Namun kekurangan dalam penerapannya adalah ketika seorang siswa memiki materi yang sudah dirangkum atau dicatat ketika di sekolah, apabila ada teman yang membutuhkan karena catatannya belum lengkap, bisa dibagikan kepada teman-teman yang lain menggunakan fitur forward. Fitur forward memudahkan untuk mengirim atau melanjutkan ke teman yang lain, tanpa harus membuka pada manajer file di gawai. Dan perlu diperhatikan bahwa fitur forwad bisa menyebabkan terjadinya penyebaran berita bohong atau hoaks itu cepat tersebar. Maka dari itu, fitur forward pada WhatsApp digunakan seperlunya saja, tidak asal-asalan membagikan sesuatu yang belum jelas kebenarannya. Peran orang tua siswa di sini sangat penting. Orang tua harus memantau apa saja yang didapatkan siswa pada WhatsApp yang digunakannya, sehingga orang tua bisa mewaspadai penyebaran berita yang tidak benar.

Pembelajaran Jarak Jauh (PJJ) atau daring (Menggunakan fitur voice note) Pembelajaran Jarak Jauh (PJJ) bisa dilakukan oleh siswa dan guru yang tergabung dalam satu grup tertentu. Pembelajaran ini bisa dilakukan sesuai dengan kebutuhan dan kesepakatan dari guru dan siswanya. Pembelajaran Jarak 
Jauh (PJJ) bisa terjadi, apabila ada pertemuan yang guru itu tidak bisa untuk mengajar, kemudian memberikan pengumuman kepada siswa supaya nanti malam untuk bisa melangsungkan PJJ tersebut. Pembelajaran Jarak Jauh (PJJ) bisa menggunakan media sosial WhatsApp. WhatsApp digunakan sebagai media untuk berdiskusi. Awalnya guru memberikan materi kepada para siswanya yang ada di grup tersebut, kemudian guru memberikan instruksi untuk mengerjakan soal atau berpendapat mengenai materi tersebut. Ketika siswa mengemukakan gagasan atau pendapatnya, harus disertai dengan nama dan nomor absen, supaya guru bisa memberikan penilaian kepada seluruh siswa yang berpartisipasi di dalam grup secara langsung. Pembelajaran ini akan lebih menarik apabila semua siswa aktif dalam pembelajaran tersebut. Guru di sini dituntut harus kreatif dalam mengembangkan materi yang akan diajarkan melalui Pembelajaran Jarak Jauh (PJJ) menggunakan WhatsApp. Fitur dari WhatsApp yang lain adalah bisa mengirim Voice notes atau perekam suara. Perekam suara bisa digunakan untuk siswa dalam mengemukakan pendapatnya. Apabila ada tes kemampuan berbicara, siswa bisa menggunakan fitur voice notes. Penilaian dari guru bisa berupa bagaimana siswa mengutarakan pendapatnya tersebut secaralisan menggunakan fitur voice notes (perekam suara).

WhatsApp memungkinkan guru untuk bisa membagikan materi melalui status. Siswa bisa membagikan materi pelajaran atau pengetahuan yang lain dengan menggunakan fitur di WhatsApp, yaitu, WhatsApp Story atau status di WhatsApp. Siswa bisa berbagi foto, video, atau link website menggunakan status. Status di
WhatsApp bisa dilihat apabila siswa saling menyimpan nomor teleponnya, sehingga bisa saling melihat status yang dibuat satu sama lainnya. WhatsApp Story merupakan salah satu media untuk berbagi dan menyimak siswa di luar grup chat yang dimiliki siswa. Berbagi foto, video, atau link website yang mungkin belum diketahui banyak orang, sehingga apabila ada siswa lain yang melihat status tersebut bisa memberikan komentar.

Membalas di status atau memberikan komentar pada status siswa yang lain merupakan salah satu bentuk kemampuan berbahasa siswa. Apabila status tersebut sudah ditanggapi oleh siswa yang lain, maka akan terjadi diskusi, sehingga status di WhatsApp bisa menjadi penting sebagai saran literasi digital siswa.

Pada tahap evaluasi: Sistem pelaksanaan ujian nasional kini sudah menggunakan CBT (Computer Based Test) yang jenis soalnya pilihan ganda. Oleh karena itu, siswa perlu dilatih agar terbiasa dengan soalsoal berbasis komputer. Hal ini juga dapat diterapkan pada ulangan harian, Ujian Tengah Semester, bahkan Ujian Akhir Semester. Langkah pembuatan kuis jenis pilihan ganda pada google classroom antara lain: membuat tugas kuis selanjutnya klik “Blank Quiz” untuk membuat kuis.

Guru dapat membuat pertanyaan secara online dan masing-masing siswa dapat memberikan jawaban terhadap pertanyaan tersebut untuk membuat kelas menjadi lebih interaktif. Google classroom adalah Sistem Manajemen Pembelajaran yang di tawarkan oleh Google untuk pendidik. Aplikasi ini menyediakan lokasi sentral untuk berkomunikasi dengan peserta didik, mengajukan pertanyaan, dan membuat tugas (Sudarsana, Putra, dan 
Astawa, 2019). Google classroom membantu memfasilitasi pembelajaran online untuk siswa pada saat pandemic covid 19 ini ini. Selain itu, google classroom memiliki potensi untuk menghemat sebagian besar waktu bagi siswan dan guru karena proses menyiapkan google classroom sangat cepat dan nyaman untuk digunakan. Waktu tidak akan terbuang sia-sia untuk mendistribusikan dokumen fisik karena tugas yang telah diberikan kepada peserta didik oleh pendidik dapat diselesaikan tepat waktu secara online. Hal tersebut membuat kendala waktu yang kurang ketika pembelajaran tatap muka berlangsung dapat teratasi.

Namun demikian, secara empirik realisasi pembelajaran daring tersebut sangat bergantung pada berbagai faktor. Pertama, pemerintah pusat mesti menjamin dengan menyediakan koneksi internet yang lancar dan stabil, subsidi kuota, bantuan perangkat digital, dan peningkatan kapasitas digital juga meminimalisir ketimpangan akses di berbagai wilayah. Harus ada alokasi anggaran secara khusus utuk mendukung lancarnya kegiatan pembelajaran daring tersebut.

Pembelajaran daring tidak dapat dilakukan jika sekolah maupun orangtua tidak memiliki kapital memadai untuk mengakses perangkatnya. Pembelajaran ini tidak akan terjadi ketika guru dan siswa sama-sama tidak memiliki komputer, handphone, atau kuota dan jaringan internet yang memadai.

\section{Kesimpulan}

Berdasarkan penelitian penggunaan Google classroom dan WhatsApp sebagai media pembelajaran daring bagi siswa
Madrasah Aliyah Nahdatul Ulama (MANU) Putra Buntet Pesantren Cirebon di masa pandemic COVID 19 dengan semangat Merdeka Belajar berjalan lancar didukung oleh lembaga yang menfasilitasi proses pembelajaran daring dan orang tua siswa yang mensuport anak-anaknya sehingga pembelajaran daring berjalan dengan baik.

\section{Daftar Pustaka}

Hakim, AB. (2016). Efektifitas Penggunaan E-learning Moodle, Google Classroom Dan Edmodo. Istatement: information system and technology management, 2(1): 2442-8337.

Hoechsmann, Michael \& Stuart R. Poyntz. (2012). Media Literacies: A Critical Introduction, UK: Blackwell Publishing.

Kementerian Pendidikan dan Kebudayaan. Surat Edaran Kemdikbud No 4 Tahun 2020 mengenai Pelaksanaan Pendidikan Dalam Masa Darurat Coronavirus Disease (Covid-19). Jakarta: Kemendikbud.

Sumber: https://www.kemdikbud.g o.id/main/blog/2020/03/mendikbud -terbitkan-se-tentang-pelaksanaanpendidikan-dalam-masa-daruratcovid19.

Komsiah, 2012: 73. https://bersamahadapikorona.kemdi kbud.go.id/panduan-pembelajaranjarak-jauh/ diakses tanggal 28 Mei 2020.

Luthra, Poornima \& Mackenzie, Sandy. 2020. 4 Ways Covid-19 Education Future

Generations. Sumber: https://www. weforum.org/agenda/2020/03/4ways-covid-19-education-futuregenerations/.

Sudarsana, K., Putra, M. A., Astawa, N. T., \& Yogantara, W. L. 2019. The Use 
of Google Classroom in The Learning Process. Journal of Physics.

Tam, Gloria \& El-Azar, Diana. 2020. 3 ways the coronavirus pandemic could reshape education. Sumber: https://www.weforum.org/ agenda/2020/03/3-wayscoronavirus-is-reshapingeducation-and-what-changesmight-be-here-to-stay/. Diakses tanggal 28 Mei 2020.

UNICEF, IRC, \& WHO. 2020. Key Messages and Actions for COVID19 Prevention and Control in Schools.

Sumber: https://www.who.int/docs/ default-source/coronaviruse/keymessages-and-actions-for-covid-19prevention-and-control-in-schoolsmarch2020.pdf?sfvrsn=baf81d52_4. 